\title{
Improved prognosis for congenital nephrotic syndrome of the Finnish type in Irish families
}

\author{
J M Savage, J A Jefferson, A P Maxwell, A E Hughes, J H Shanks, D Gill
}

\begin{abstract}
Congenital nephrotic syndrome of the Finnish type is a rare autosomal recessive disease with a high infant mortality without aggressive treatment. The biochemical basis of the disease is not understood fully but the disease locus has been mapped recently to chromosome 19q12q13.1 in Finnish families. This paper describes the clinical features and outcome of 20 patients in Ireland with congenital nephrotic syndrome of the Finnish type who have presented since 1980. Before 1987, all infants died by the age of 3 years. After the introduction of daily intravenous albumin infusion, nutritional support, elective bilateral nephrectomy, and renal transplantation, mortality in the past decade has fallen to $30 \%$, with no deaths in the past five years. Genetic linkage analysis was performed in six families in whom DNA was available and the locus responsible was mapped to the same region on chromosome 19 as in Finnish families, suggesting that Irish families share the same disease locus. (Arch Dis Child 1999;80:466-469)
\end{abstract}

Keywords: congenital nephrotic syndrome; linkage; prognosis

Department of Child Health, The Queen's University of Belfast, Belfast BT12 6BJ, UK J M Savage

Department of Genetics, The Queen's University of Belfast

A E Hughes

Department of Pathology, The Queen's University of Belfast

J H Shanks

Department of Nephrology, Belfast City Hospital, Belfast BT9 7AB, UK

J A Jefferson

A P Maxwell

The Children's Hospital, Temple Street, Dublin 1, Republic of Ireland D Gill

Correspondence to: Dr Savage.

Accepted 13 November 1998 (at 35-38 weeks), showing signs of fetal distress, and are below gestational weight for age. Placentomegaly accounting for more than
$25 \%$ of total birth weight is a characteristic feature. Classically, the newborn has a small, low bridged nose, widely separated cranial sutures, with large anterior and posterior fontanelles, and signs of delayed ossification. ${ }^{6}$ The features of nephrotic syndrome predominate and appear early. Proteinuria is typically severe $(>20 \mathrm{~g} / 1$ when serum albumin is corrected to $>15 \mathrm{~g} / \mathrm{l}$ ) and associated with pronounced hypoalbuminaemia $(<10 \mathrm{~g} / 1$ at presentation). ${ }^{7}$ Most are oedematous at birth or develop typical features within the first week. Ascites with abdominal distension occurs in most cases. Ultrasonography reveals enlarged echogenic kidneys, with loss of corticomedullary differentiation, and the diagnosis is confirmed by renal biopsy showing the characteristic irregular dilatation of proximal convoluted tubules ("microcystic disease"). Renal function is usually normal for the first 6 months, but the babies fail to thrive and are particularly prone to infection and thromboembolism. Children who survive these early complications progress to renal failure and, without treatment, die in early childhood. Other recognised features include hypothyroidism, seizures, umbilical herniae, bony deformities, and developmental delay. ${ }^{8}$

Historically, all children died, usually within the first 6 months of life, but now with aggressive treatment an extended survival can be achieved. ${ }^{9}$ Early intravenous albumin supplementation to replace renal losses, nutritional support, vitamin and thyroxine replacement, and rapid management of the complications of infection and thrombosis allow initial stabilisation. We use a $20 \%$ albumin solution to deliver $3-4 \mathrm{~g} / \mathrm{kg}$ albumin intravenously, initially in two divided doses of three to four hours duration, and later as a single overnight infusion over six to eight hours. Frusemide $0.5 \mathrm{mg} / \mathrm{kg}$ is given with the albumin infusion. Nutrition is supplemented with nasogastric or gastrotomy tube feeding delivering $0.5 \mathrm{MJ} / \mathrm{kg}, 4 \mathrm{~g} / \mathrm{kg}$ protein each day and dietary fat manipulation. We follow this with bilateral nephrectomy at age 6-10 months and peritoneal dialysis leading to improvements in feeding and growth, which allow the child to reach a weight and body size (usually 8-9 kg) at which renal transplantation can be successful. Angiotensin converting enzyme inhibition and indomethacin to diminish urinary protein loss has been used as a successful alternative to bilateral nephrectomy in two patients. ${ }^{10}$

The condition is inherited as an autosomal recessive trait with a gene frequency of $1 / 200$ in Finland. ${ }^{11}$ Until recently, the biochemical defect in this disease was unknown but in view 
of the heavy proteinuria, abnormalities in components of the glomerular filtration barrier have been suggested. In 1994, using a candidate gene approach to linkage analysis Kestila et al excluded defects in the genes encoding the type IV collagen chains $\alpha 1-\alpha 4$; the B1e, B2e, and B2t chains of laminin; and the perlecan gene. $^{12}$ In 1994, using a random mapping approach to linkage analysis, the same group assigned the gene responsible for Finnish congenital nephrotic syndrome (the CNF gene) to the long arm of chromosome $19 .{ }^{13}$ Furthermore, linkage disequilibrium was demonstrated, suggesting a founder effect owing to a common ancestral mutation in this population. In 1998, Kestila's group identified a gene on which four different mutations segregate with the disease. ${ }^{14}$ The gene encodes a 1241 amino acid transmembrane protein called nephrin, whose function remains unclear.

\section{Methods}

PATIENTS AND CLINICAL FEATURES

Since 1980, there have been 22 children with congenital nephrotic syndrome diagnosed at two referral centres for paediatric nephrology in Ireland (The Children's Hospital, Temple Street, Dublin and The Royal Belfast Hospital for Sick Children, Belfast). Twenty of these children, from 15 apparently unrelated families, had Finnish congenital nephrotic syndrome. There was no evidence of consanguinity or Finnish ancestry in any of these families. Two children had diffuse mesangial sclerosis and are not described further.

All children with the Finnish congenital nephrotic syndrome presented within the first 5 weeks of life, most at birth. Details of pregnancy were available in nine cases, with a normal course in seven. In one case, isolated proteinuria was present for the last 10 days; and in the second, haematuria, proteinuria, and hypertension developed in the latter stages of pregnancy. The mean gestational age was 36.5 weeks, range $30-40(n=8)$ and the mean birth weight was $2.81 \mathrm{~kg}$, range $1.62-3.85$ $(n=16)$. Four babies were of low birth weight (less than $2500 \mathrm{~g}$ ). Placental weight was available in seven cases and in each there was pronounced placentomegaly of between 38\% and $45 \%$ of total birth weight (mean placental weight, $979 \mathrm{~g}$ ).

Oedema was the commonest presenting feature. Proteinuria was heavy in most children, up to $40 \mathrm{~g} / 24$ hours. The lowest recorded value of proteinuria was $2.4 \mathrm{~g} / 24$ hours, but this was nevertheless associated with severe oedema and ascites and reflected a low serum albumin. Renal function was normal or only mildly impaired at presentation.

Infection was a common problem: two children presented with Streptococcus pneumoniae peritonitis and both died within a few months of birth. However, others managed to survive life threatening infections including one patient who developed Haemophilus influenzae meningitis aged 14 months and another who recovered from pseudomonas septicaemia. Four children had neonatal hypothyroid-
Table 1 Results of genetic analysis of inheritance of chromosome 19 markers flanking known CNF locus

\begin{tabular}{llll}
\hline Marker & Maplocation & $\begin{array}{c}\text { Number of } \\
\text { individuals }\end{array}$ & Heterozygosity \\
\hline D19S416 & 19q13.1 & 11 & 0.80 \\
D19S224 & $19 q 13.1$ & 9 & 0.81 \\
D19S220 & $19 q 13.1$ & 10 & 0.84 \\
D19S422 & $19 q 13.1$ & 9 & 0.80 \\
D19S223 & 19q13.1 & 9 & 0.81 \\
\hline
\end{tabular}

ism requiring thyroid replacement treatment, possibly as a result of loss of thyroid binding globulin in the urine.

Before 1987, five children presented with the Finnish congenital nephrotic syndrome and all died from sepsis (mean age, 10 months; range, 2-18). Between 1987 and 1997, 15 children presented with congenital nephrotic syndrome of the Finnish type, of whom five have died (mean age, 24 months; range, 1-50). Two children died from sepsis within the first 12 months and one child died perinatally of cerebral palsy. Two children died within days of renal transplantation, one from thromboembolic complications aged 3.1 years and the second developed acute respiratory distress syndrome and pneumonia aged 4.2 years.

Thrombotic complications have developed in a large number of children. In three patients, computed tomography scans of the brain identified evidence of intracerebral lesions shortly after birth, suggesting intrauterine thrombosis. One presented with noticeable spastic cerebral palsy, one with unilateral hemiplegia, and the third with seizures. A further child was found to have an asymptomatic iliac vein thrombosis at the time of transplantation and others have had major vessel thromboses in association with intravenous catheterisation. We now believe that these patients should receive anticoagulant treatment with warfarin after the neonatal period.

The reduction in mortality secondary to Finnish congenital nephrotic syndrome is related directly to the introduction of aggressive interventional treatment in the past decade. ${ }^{9}$ The aim is to sustain nutrition and growth so that children can tolerate bilateral nephrectomy at 1 year of age, with subsequent management of renal failure with cycling peritoneal dialysis until a suitable weight and size for renal transplantation is achieved.

Since 1987, all children surviving the initial 6-12 months have undergone bilateral nephrectomy $(n=12)$ at a mean age of 15 months. This was performed as a two stage operation in three children but there did not appear to be a clinical advantage in this. Renal transplantation has been performed in 10 children (mean age, 39 months; range 25-51) with a one year graft survival of $80 \%$. Two children died in the perioperative period. In addition, one child lost a graft at 18 months from rejection, but has since had a second successful living related donor transplant. A second child who underwent renal transplantation aged 41 months developed recurrent nephrotic syndrome in the graft six months posttransplantation after an upper respiratory tract infection. Biopsies of the renal allograft showed 

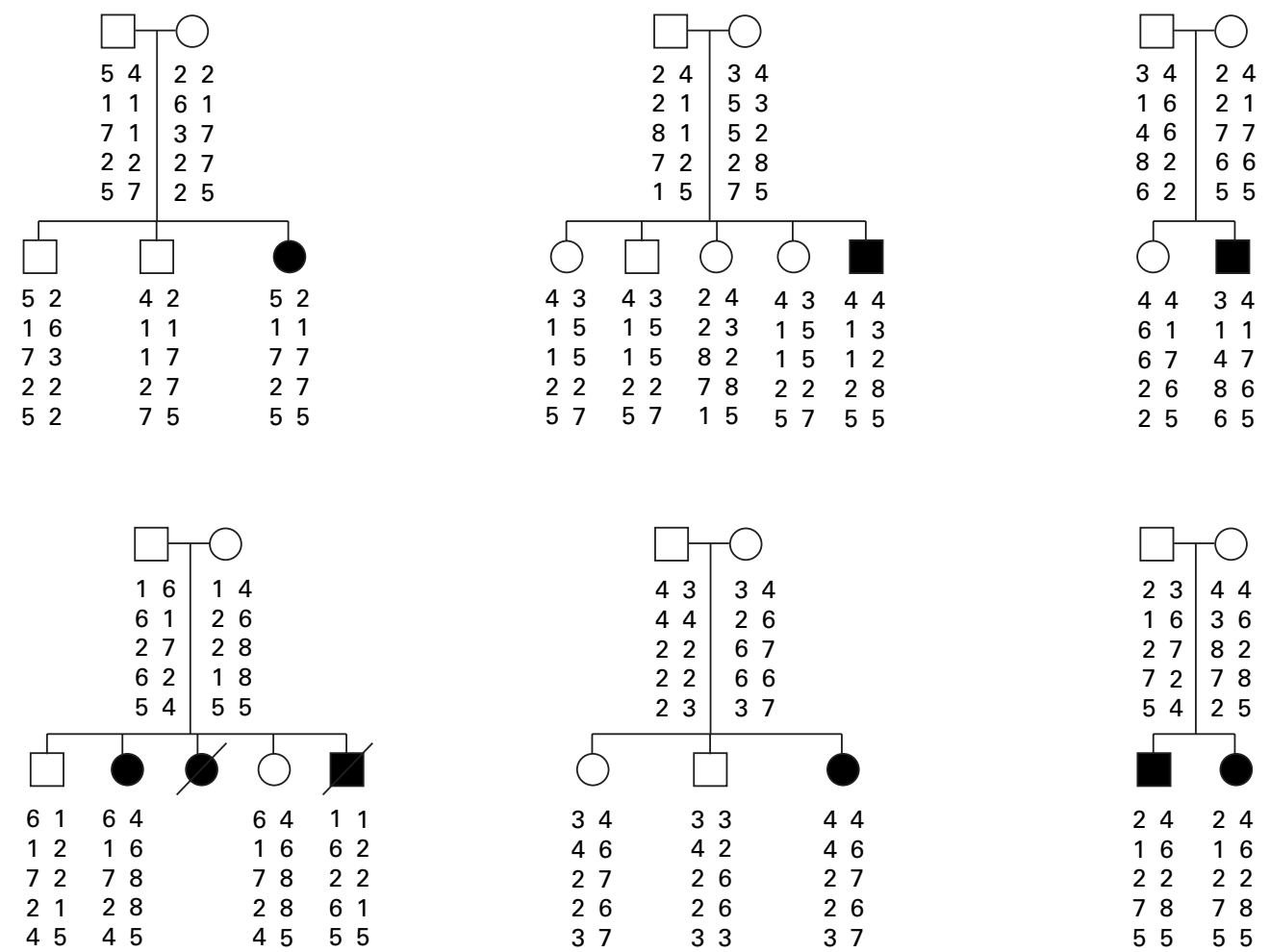

Figure 1 Family pedigree showing haplotypes for markers D19S416, D19S224, D19S220, D19S422, and D19S223. Squares, boys/men; circles, girls/women; closed symbols, affected individuals.

a de novo mesangial proliferative glomerulonephritis rather than evidence of recurrent disease. The child required a period of haemodialysis but subsequently recovered satisfactory graft function. Another child developed severe proteinuria $(2.1 \mathrm{~g} / 24$ hours at 15 months after transplantation), which resolved with a temporary increase in steroid dosage and has not recurred at two years' follow up.

Currently, 10 of the children are alive (mean age, 6.5 years; range 1.5-10), eight with functioning renal transplants and two on dialysis awaiting transplantation.

GENETIC LINKAGE ANALYSIS

We extracted DNA from the peripheral blood of 38 members from 10 families with congenital nephrotic syndrome of the Finnish type and analysed it for the inheritance of five informative microsatellite polymorphisms flanking the CNF gene locus on chromosome 19 (table 1$).{ }^{15}$ Seven of these families had at least one affected and one unaffected child and were suitable for linkage analysis. In three families the affected child had no siblings.

We obtained all flanking microsatellite oligoprimers from Research Genetics (Huntsville, Alabama, USA). We used the polymerase chain

Table 2 Results of two point linkage analysis between disease gene and chromosome 19 markers

\begin{tabular}{llllllll}
\hline \multirow{7}{*}{ Marker } & \multicolumn{2}{l}{ Theta value } & & & & \\
\cline { 2 - 8 } & 0 & 0.01 & 0.05 & 0.1 & 0.2 & 0.3 & 0.4 \\
\hline D19S416 & 1.98 & 1.91 & 1.63 & 1.30 & 0.74 & 0.33 & 0.08 \\
D19S224 & 1.98 & 1.91 & 1.64 & 1.31 & 0.76 & 0.34 & 0.09 \\
D19S220 & 1.98 & 1.90 & 1.59 & 1.23 & 0.65 & 0.27 & 0.06 \\
D19S422 & 2.28 & 2.19 & 1.86 & 1.48 & 0.83 & 0.36 & 0.09 \\
D19S223 & 2.03 & 1.96 & 1.69 & 1.37 & 0.80 & 0.37 & 0.10 \\
\hline
\end{tabular}

reaction (PCR) to amplify the polymorphic region in a reaction volume of $10 \mu$ containing $25 \mathrm{ng}$ DNA, $200 \mu \mathrm{mol} \mathrm{dNTP}, 0.25 \mu \mathrm{M}$ each primer (one of which was end labelled with $\left.\left[\gamma^{32} \mathrm{P}\right] \mathrm{ATP}\right), 1.5 \mathrm{mM} \mathrm{MgCl}, 1 \times$ PCR buffer, and $0.2 \mathrm{U}$ Taq polymerase. We denatured samples for three minutes at $94^{\circ} \mathrm{C}$, followed by 35 cycles of amplification at $94^{\circ} \mathrm{C}$ for one minute, $55^{\circ} \mathrm{C}$ for one minute, and $72^{\circ} \mathrm{C}$ for one minute, and finally an extension step at $72^{\circ} \mathrm{C}$ for a further five minutes. We separated PCR products by electrophoresis on a $6 \%$ denaturing polyacrylamide gel and visualised them by autoradiography.

We calculated lod scores using the MLINK program from the computer package LINKAGE (version 5.1). ${ }^{16}$

\section{Results}

Figure 1 gives the allele scores. Positive lod scores were achieved with all five markers using two point linkage analysis. The highest lod score at zero recombination was achieved with the marker D19S422 (table 2). There were no cases of recombination with any of the markers. Multipoint linkage analysis raised the lod score to 2.60 between the markers D19S224 and D19S422. There was no evidence of a common haplotype with these markers to indicate linkage disequilibium.

\section{Discussion}

Although Finnish congenital nephrotic syndrome is a rare disease, our series of patients is one of the largest groups described outside Finland. Over the past 15 years, 20 children have presented with the disease in Ireland and of these 10 are still alive. In early years, the 
prognosis was poor, with most children dying within the 1st year of life, predominantly from sepsis. Since 1987, the outlook has been transformed by much more aggressive treatment. All children are now treated initially with daily intravenous albumin infusions. Nutrition is supplemented with nasogastric or gastrostomy tube feeds high in energy and protein. All children are anticoagulated routinely with warfarin after the neonatal period. Early bilateral nephrectomy is used to prevent the massive urinary protein losses. After dialysis and subsequent renal transplantation many of these children have now achieved an excellent quality of life and good long term prognosis.

Many of the hereditary renal diseases that have recently been analysed at a molecular level have revealed genetic heterogeneity. At least two loci have been identified for adult polycystic kidney disease (PKD1 and PKD2) and Alport syndrome (COL4A5, COL4A3, and COL4A4). In Finnish families, the CNF locus was mapped to chromosome $19 \mathrm{q} 13.1^{13}$ and this has been confirmed recently in populations of non-Finnish ancestry. ${ }^{17} 18$ To search for genetic heterogeneity in the Irish families we performed linkage analysis using microsatellite markers on chromosome 19. Because linkage dysequilibrium had been demonstrated in Finnish families with the markers D19S220 and D19S224, recombination events with these markers in any of the Irish families would suggest heterogeneity. Using five polymorphic microsatellite markers in this region, the disease gene was mapped to the same area on chromosome 19 as in Finnish families, with a maximum lod score of 2.6. This demonstrates a further non-Finnish population in whom the disease has been mapped to chromosome 19 consistent with locus homogeneity.

Finnish congenital nephrotic syndrome is an extremely severe disease of early childhood and prenatal diagnosis is often requested by families who have previously had an affected child. A raised $\alpha$ fetoprotein concentration in the amniotic fluid caused by fetal proteinuria has been used to identify those at risk, but this is not a specific test and can only be performed after the 15 th week. ${ }^{19}$ An increase in maternal serum $\alpha$ fetoprotein can also be used as a less sensitive general screening method. ${ }^{20}$ Improved prenatal diagnosis of Finnish congenital nephrotic syndrome, based on DNA analysis of chorionic villus tissue, is now possible. ${ }^{21}$ Results of subsequent linkage and haplotype analyses can reduce the risk of false positive diagnosis based on $\alpha$ fetoprotein concentrations alone.

The identification of the mutated gene in congenital nephrotic syndrome of the Finnish type will allow for accurate prenatal and carrier detection in those at risk without the need for family studies and will provide valuable insight into the mechanisms of proteinuria and glomerular function. Common haplotypes of markers have been described in both Finnish and non-Finnish affected families, suggesting that one or two ancestral mutations account for most cases of Finnish congenital nephrotic syndrome. Currently, we are examining additional markers in the Irish families in an attempt to define a common haplotype in these families, which might further narrow down the region of interest and accelerate the cloning of the CNF gene.

The authors thank the Northern Ireland Kidney Research Fund and the Children's Kidney Fund for supporting this work.

1 Habib R, Loirat C, Gubler MC, et al. The nephropathy associated with male pseudohermaphroditism and Wilms' tumor (Drash syndrome): a distinctive glomerular lesionreport of 10 cases. Clin Nephrol 1985;24: 269-78.

2 Kaplan BS, Wiglesworth FW, Marks MI, Drummond KN. The glomerulopathy of congenital syphilis - an immune deposit disease. F Pediatr 1972;81:1154-6.

3 Shahin B, Papadopoulou ZL, Jenis EH. Congenital nephrotic syndrome associated with congenital toxoplasmosis. F Pediatr 1974;85:366-70.

4 Batisky DL, Roy S, Gaber LW. Congenital nephrosis and neonatal cytomegalovirus infection: a clinical association. Pediatr Nephrol 1993;7:741-3.

5 Huttunen N-P. Congenital nephrotic syndrome of Finnish type: study of 75 patients. Arch Dis Child 1976;51:344-8.

6 Morgan G, Postlethwaite RJ, Savage JM. Physical abnorMorgan G, Postlethwaite RJ, Savage JM. Physical abnor-
malities in children with congenital nephrotic syndrome. Arch Dis Child 1981; 56:959-61.

7 Holmberg C, Laine J, Ronnholm K, et al. Congenital nephrotic syndrome. Kidney Int 1996;49:S51-6.

8 Hallman N, Norio R, Kouvalainen K. Main features of the congenital nephrotic syndrome. Acta Paediatr Scand 1976; 172:75-7.

9 Holmberg C, Antikainen M, Ronnholom K, Ala-Houhala $M$, Jalanko $H$. Management of congenital nephrotic syndrome of the Finnish type. Pediatr Nephrol 1995;9:8793.

10 Pomeranz A, Wolach B, Bernheim J, Korzets Z, Bernheim J. Successful treatment of Finnish congenital nephrotic syndrome with captopril and indomethacin. F Pediatr 1995; 126:140-2.

Norio R. Heredity in congenital nephrotic syndrome. Ann Paediatr Fenn 1966;12:1-94.

12 Kestila M, Mannikko M, Holmberg C, et al. Exclusion of eight genes as mutated loci in congenital nephrotic syndrome of the Finnish type. Kidney Int 1994;45:986-90.

13 Kestila M, Mannikko M, Holmberg C, et al. Congenital nephrotic syndrome of the Finnish type maps to the long arm of chromosome 19. Am f Hum Genet 1994;54:757-64.

14 Kestila M, Lenkkeri U, Mannikko M, et al. Positionally cloned gene for a novel glomerular protein-nephrin-is mutated in congenital nephrotic syndrome. Mol Cell 1998; 1:575-82.

15 Mannikko M, Kestila M, Holmberg C, et al. Fine mapping and haplotype analysis of the locus for congenital nephrotic syndrome on chromosome 19q13.1. Am f Hum Genet 1995;57:1377-83.

16 Lathrop G, Lalouel J. Easy calculations of lod scores and genetic risks on small computers. Am f Hum Genet 1984;36:460-5.

17 Fuchshuber A, Niaudet P, Gribouval O, et al. Congenital nephrotic syndrome of the Finnish type: linkage to the locus in a non-Finnish population. Pediatr Nephrol 1996;10: $135-8$.

18 Mannikko M, Lenkerri U, Kashtan C, et al. Haplotype analysis of congenital nephrotic syndrome of the Finnish type in non-Finnish families. F Am Soc Nephrol 1996;7: $2700-3$

19 Seppala M, Rapola J, Huttenen N-P, et al. Congenital nephrotic syndrome: prenatal diagnosis and genetic counselling by estimation of amniotic fluid and maternal alphafetoprotein. Lancet 1976;ii:123-5.

20 Ryynanen M, Seppala M, Kuusela P, et al. Antenatal screening for congenital nephrosis in Finland by maternal serum alpha-fetoprotein. Br f Obstet Gynaecol 1993;90:437-42.

alpha-fetoprotein. Br f Obstet Gynaecol 1993;90:437-42.
Mannikko M, Kestila M, Lenkerri U, et al. Improved prenatal diagnosis of the congenital nephrotic syndrome of the Finnish type based on DNA analysis. Kidney Int 1997;51: 868-72. 